UDC 378.1

\title{
BLENDED LEARNING MODEL IN THE SYSTEM OF HIGHER EDUCATION
}

\author{
K. A. Lisetskyi \\ Kyiv, National Technical University of Ukraine "Kyiv Polytechnic Institute" \\ lis.kostiantyn@gmail.com
}

\begin{abstract}
The article deals with the introduction of blended learning in the system of higher education. The author describes basic tendencies in implementation of blended learning system, which in different proportions combines the elements of traditional and distance learning. Organization of the online learning course and the components of blended learning are characterized in detail. The author provides the definition of the term "blended learning". The possibilities and advantages of blended learning in combination with traditional or face-to-face and independent or distance learning are reviewed. The emphasis is put on the use of distance learning in the course of traditional full-time training. In the article various existing blended learning models and the ways of their adaptation are considered. It is shown that the use of different forms of online learning in combination with traditional learning makes it possible to achieve higher efficiency of education, but the transition from traditional forms of training into the area of free educational space is not easy and requires a lot of effort.
\end{abstract}

Key words: online learning, distance learning, blended learning model, remote technologies, computermediated activity, electronic resources.

Introduction. In modern conditions, the role of education and knowledge in the world plays a dominant role. This role is of great importance for the development of the whole society and personal development. Higher education promotes the development of students' knowledge and skills, contributing to the development of both the individual and society as a whole.

There are several factors that influence the development of education nowadays. They involve: the development of technologies, research area, and the daily increase of scientific and technical information.

During the last century, there have been significant changes in defining the purposes and methods of modern education. While previous goal was to prepare graduates who possess basic skills, recent attention is drawn to the high level of knowledge and the development of problemsolving skills in respective areas, the ability to adapt to the needs of modern life. Besides, each institution of higher education is facing the problem of the growing number of students, and decrease of assignations for training; most students try to combine the learning process and to obtain practical work experience.

These challenges are pushing the majority of higher education institutions to provide new learning technologies. With the introduction of online training that enables anywhere and at any time to acquire knowledge, the first step to meet the needs of higher education has been made. The next step is the introduction of blended learning model that combines the advantages of online learning with stationary training [2].

The purpose of this article is to analyze the introduction of blended learning model in higher education. The tasks of the article are the following: to outline the advantages of blended learning; to demonstrate a course structure of online learning; to present models of blended learning.

Definition, structure and advantages of blended learning. Blended learning is an educational course, in which students can gain knowledge on their own, and in person with the lecturer. This approach makes it possible to control the time, place, pace and ways of learning the material. Students learn face-to-face in the class performing Computer-Mediated Activities with the use of computers, mobile devices and special educational programs or platforms. This system has several advantages:

- mastering the essential new knowledge by using electronic resources;

- balancing the students' knowledge through self-study materials and tasks proposed by a lecturer. There is an opportunity for students with a higher proficiency level to study material of higher complexity. Thus, the principle of individual approach to studenti is realized;

- taking into account students' individual characteristics in relation to the perception of information (for example, if one of the students needs more time for mastering new material); 
- stimulating the development of students' self-learning skills. This especially may be relevant while implementing group projects;

- saving time in the classes by passing certain topics for self study;

- mutual control of the learning process from the teacher's side and through student's selfevaluation;

- permanent access to the necessary training materials and therefore the opportunity for students constantly review the material;

- improving communication between a student and a teacher. Communication takes the form of mentoring and allows a teacher to coordinate students' activities and give recommendations how to improve their knowledge.

Such synonyms as Blended learning or Hybrid Learning, Technology-Mediated Instruction, Web-Enhanced Instruction and Mixed-Model Instruction are often used.

Basically blended learning consists of three parts: traditional in-class training, students' independent work, online learning [1].

The amount of online courses is constantly increasing among universities worldwide. According to statistics, currently, $62.4 \%$ of overseas higher education institutions are implementing online learning courses and programs compared to 2002 where the figure was much lower $-34.5 \%$. Besides, it should be noted that most lecturers in higher education institutions in general positively support the concept of blended learning and many of them use blended learning in varying forms. According to the Center of Digital Education (CDE) $90 \%$ of the surveyed teachers use creative approaches in teaching subjects through blended learning technologies. When in the interview the topic of blended learning benefits was raised, $92 \%$ of respondents agreed on 3 key points:

1. The ability to offer an alternative model of learning;

2. The ability to offer distance learning model;

3. Enhancing the role of a student in the learning process.

More than a half of the respondents also emphasized the improving of performance, better use of audience and reducing the cost of education as the benefits of this type of study. Regarding the role of technologies in the process of blended learning support, polled respondents indicated such advantages as the ability of teachers to communicate with students at any time and opportunity for the teacher to assess how students use materials of blended learning [5].

The main task of the teacher is to compose the course in a clear and understandable manner and to distribute the training material. It is necessary to decide what to study in the classes, what students can learn, train and solve at home, which tasks are suitable for individual classes and which are good for group work on the project. It is assumed that the basic course is taught in face-to-face classes, and the extended and deepened is learned distantly. It is important to organize face-to-face lessons in the formats of projects, presentations or discussions between students and teachers. Remote unit may include group projects, creative tasks, practical tasks, reference materials, intermediate and verification tests, and also high complexity tasks for successful students. Basic knowledge assessment can be made in classes [6].

The organization of the online learning course. The Course structure for online learning is especially important for students because the loss of consistency in the performance of tasks is the most common cause of failure in online learning:

- training in online environment requires students to be self-motivated, self-disciplined, self-directed. That is in online environment, students have to take an active role in learning, they can easily lose interest in learning if they are not familiar with the structure, content and methodology of performing the online course exercises;

- as students have many questions regarding the performance of an online course, the great emphasis is focused on supporting communication between a teacher and a student;

- course structure must be logical and consistent. In other words, it should reflect the natural order within the content;

- where possible, the content of the course is to be structured in groups of tasks, such as discussions, projects, reading activities or video;

- students should be provided with a detailed description of the structure of the course. 
Online course may consist of sections; each section is divided into topics that are in hierarchical order. There are several models of blended learning [3].

Model 1. "Unit by Unit". Material is divided into Units, which in turn are subdivided into Chapters, containing particular Topics;

Model 2. "Module by Module" ("Chapter by Chapter"). Content is divided into modules. Each module consists of theory, exercises and tests. The theoretical material comprises a variety of video materials and PowerPoint slides. The activities may also include online discussions and performance of various tasks.

Model 3. "Week by week". Each week consists of material presentation, various tasks and tests to be performed within limited period of time.

Model 4. "Project by Project". The course content is divided into projects to be that must be completed within several weeks. Each week specific objectives are carried out.

Let us consider existing blended learning models which differ in accents, needs and fees.

1. Face-to-Face Driver. This model involves mastering most of the curriculum in the classroom. It often presupposes performing some tasks on computers.

2. Rotation Model. There is a rotation schedule of the traditional face-to-face class studies and online self-study in a private mode (e.g. via the Internet using reference plan made by a teacher in a blended program; on a special website).

3. Flex Model. This model involves learning most of the material online. Usually, when an online platform is used, a teacher helps students when needed to work in small groups or individually. The teacher acts as a coordinator who organizes consultations to master topics which are hard for understanding.

4. Online lab. This model involves learning on a special website of the educational institution. Online platform is used to transfer the whole course in the full-time classes. Such training is supervised by a teacher. This program can be combined as a part of regular schedule.

5. Self-Blend Model. This model makes it possible to choose additional courses for basic training. A student decides which course he needs to supplement via remote online sessions. Various institutions can serve as educational service providers. To be effective, this model of blended learning presupposes a high degree of student motivation to learn.

6. Online Driver Model. This model provides the opportunity for students to study particular courses for bigger flexibility and in spare time. Basically, this model provides online training through the platform and remote contact with a teacher. However, on demand meetings with the teacher can be provided.

It should be noted that the aforementioned models are not often used in pure form, as a rule, it depends on the situation and the learning environment, the target group, knowledge level and goals. Therefore, each of the models involves the development of an applied scenario of roles, functionality, didactic goals and resources. For example, in the combination of models "Face-toFace" and "Rotation", students have 2 classes per week, one of which is full-time in the classroom, the other is remote in the online environment. Combining the models "Face-to-Face" and "Flex" can be used in traditional classes 2-3 times a week, the recommended time for online learning amounts at least $20 \%$. In the model "Online driver" students meet a teacher once a month, and the rest of the academic year they work in online environment. The model "Face-to-Face" is used in intensive training [4].

Conclusions. The importance of the transition to e-learning resources in terms of university education does not require additional arguments. This is dictated not only by learning objectives, but also the formation of important qualities in students such as motivation to learn, the ability to consciously choose the direction and course of learning, the ability to distribute and manage one's own academic freedoms. The transition from traditional forms of training into the area of free educational space is not easy and requires a lot of effort to find the best methods and mechanisms of managing this process.

The use of blended learning method should lead to the change of quality in education. The variety of resources of blended learning electronic component opens up new possibilities for the presentation of educational material in an accessible and interesting way. 
The introduction of online learning is caused by the development of communicative technologies. Although the situation in higher education is changing, there are still a lot of questions how one can better use technologies to achieve the learning objectives in terms of inclusion of students in the process of critical thinking and discourse.

\section{REFERENCES}

1. Bonk C. J. Handbook of blended learning: Global Perspectives, local design / C.J. Bonk, C.R. Gramam. San Francisco. CA: Pfeiffer Publishing, 2006. - 624 p.

2. Garrison D. R. Blended Learning in Higher Education: Framework, Principles, and Guidelines [Electronic resource]. - Retrieved from: http://www.bookdaily.com/book/275372/blended-learning-in-higher-educationframework-principles-and-guidelines\#TD5FjIEMSmoubuTG.99

3. Designing the Online Course Structure. Institute for teaching and Learning Excellence [Electronic resource]. Retrieved from: http://itle.okstate.edu/fd/online_teaching/coursestructure.html

4. Краснова Т.И. Смешанное обучение как новая форма организации языкового образования в неязыковом вузе /Т.И. Краснова, Т.В. Сидоренко // Образовательные технологии и общество [Електронний pecypc]. - Режим доступу: http://cyberleninka.ru/article/n/smeshannoe-obuchenie-kak-novaya-forma-organizatsiiyazykovogo-obrazovaniya-v-neyazykovom-vuze

5. Realizing the Full Potential of Blended Learning. A strategy paper from Center for Digital Education [Electronic resource]. - Retrieved from: http://echo360.com/sites/default/files/CDE12\%20STRATEGY\%20Echo360-V.pdf

6. Irvine V. Realigning Higher Education for the 21st-Century Learning through Multi-Access Learning [Electronic resource]. - Retrieved from: http://jolt.merlot.org/vol9no2/irvine_0613.htm

\section{REFERENCES}

1. Bonk, C.J. \& Gramam, C.R. (2005). Handbook of blended learning: Global Perspectives, local design. San Francisco. CA: Pfeiffer Publishing.

2. Garrison, D.R.. Blended Learning in Higher Education: Framework, Principles, and Guidelines. Retrieved from http://www.bookdaily.com/book/275372/blended-learning-in-higher-education-framework-principles-andguidelines\#TD5FjIEMSmoubuTG.99

3. Designing the Online Course Structure. Institute for teaching and Learning Excellence. Retrieved from http://itle.okstate.edu/fd/online_teaching/coursestructure.html

4. Krasnova, T. \& Sydorenko, T (2014). Blended learning as a new form of language education organization in non-language higher. Educational technologies and society. Retrieved from http://cyberleninka.ru/article/n/smeshannoeobuchenie-kak-novaya-forma-organizatsii-yazykovogo-obrazovaniya-v-neyazykovom-vuze [in Russian]

5. Realizing the Full Potential of Blended Learning. A strategy paper from Center for Digital Education. Retrieved from http://echo360.com/sites/default/files/CDE12\%20STRATEGY\%20Echo360-V.pdf

6. Irvine, V. (2013). Realigning Higher Education for the 21st-Century Learning through Multi-Access Learning. Retrieved from http://jolt.merlot.org/vol9no2/irvine_0613.htm

\section{К. А. Лісецький. Модель змішаного навчання в системі вищої освіти}

У статті розглядається запровадження моделі змішаного навчання в системі вищої освіти. Аналізуються основні тенденції в використанні системи змішаного навчання, яке в різних пропорціях поєднує елементи традиційного і дистанційного навчання. Детально характеризуеться організація курсу он-лайн навчання, складові змішаного навчання. Автор дає визначення терміну «змішане навчання». Розглянуто можливості і переваги використання змішаного навчання в навчальному процесі. В статті ретельно визначені завдання, які стоять перед викладачем та розглядаються різні моделі змішаного навчання. Показано, що використання різних форм он-лайн навчання 3 поєднанням 3 традиційною формою навчання дає можливість досягти високої ефективності в навчальному процесі.

Ключові слова: електронне навчання, змішане навчання, онлайн навчання, елементи дистанційного навчання, модель змішаного навчання, дистанційні технології, інформаційно-комунікативні технології, комунікація.

\section{К. А. Лисецкий. Модель смешанного обучения в системе высшего образования}

В статье рассматривается внедрение модели смешанного обучения в системе высшего образования. Анализируются основные тенденции в использовании системы смешанного обучения, которое в разных пропорциях сочетает элементы традиционного и дистанционного обучения. Подробно характеризуется организация курса онлайн обучения, составляющие смешанного обучения. Автор дает определение термина «смешанное обучение». Рассмотрены возможности и преимущества использования смешанного обучения в учебном процессе. В статье тщательно определены задачи, стоящие перед преподавателем и рассматриваются различные модели смешанного обучения. Показано, что использование различных форм онлайн обучения с сочетанием с традиционной формой обучения позволяет достичь высокой эффективности в учебном процессе.

Ключевые слова: электронное обучение, смешанное обучение, онлайн обучение, элементы дистанционного обучения, модель смешанного обучения, дистанционные технологии, информационнокоммуникативные технологии, коммуникация. 